\title{
Critical Success Factors for Project Management Information System in Construction
}

\author{
Seul Ki Lee ${ }^{1}$ and Jung Ho Yu
}

\begin{abstract}
With a focus on different aspects of PMIS in construction projects, various sets of critical success factors (CSFs) have been suggested in the literature such as IS Success Model by various researchers. It is crucial to explore the relative importance and groupings of these factors. This paper aims to identify CSFs associated with Project Management Information System (PMIS) in construction projects, and explore their ranking and underlying relationship.

CSFs for PMIS identified through a literature review, and consolidated by interviews and pilot studies with professionals in construction industry. A questionnaire instrument was sent out to experienced users (Construction Manager and Constructor) in Korea, and 253 completed questionnaires were retrieved. To increase the generalizability of the results, the respondents were spread across construction site.

Using factor analysis and considering the high importance of the factor, CSFs were grouped into three dimensions. All these three groupings and their relationship were included in a framework for successful PMIS in construction projects. These findings help to clarify what the high prioritized factors are, and could also be used as an assessment tool to evaluate the performance of PMIS and thus help to identify areas for improvement.
\end{abstract}

Keywords: Critical Success Factors (CSFs), IS Success Model, Project Management Information System (PMIS), Construction projects

\section{INTRODUCTION}

The importance of information technology (IT/IS) in the architectural/engineering/construction $(\mathrm{A} / \mathrm{E} / \mathrm{C})$ industry has grown exponentially over the past few decades ( $\mathrm{Yu}$ and Lee 2006). As one of the key IT applications, the project management information system (PMIS) has played a significant role in construction management processes. The reason for this is that PMIS is an information system for gathering, integrating, and disseminating the output of project management processes among project participants, and is used to support all aspects of a project from initiating through to closing.

In order to continuously increase the efficacy of PMIS, we need to know the critical success factors (CSFs) for PMIS. This means that what users feel of importance should be identified and managed more significantly. In a similar context, there has been a great deal of research on general information system (IS) success factors and success models. However, there has been neither significant research on CSFs for PMIS (Yu and Lee 2004) nor studies on the actual use and impacts of these systems (Raymond and Bergeron 2008).

In general, there are two types of PMISs in the construction field: One is these is that which is developed and used by individual construction companies. The other is the ASP (Application Service Provider)-based PMIS which is developed for general construction projects but can be customized for specific construction projects. The former can be considered as one of the information systems (e.g. MIS and ERP systems, etc.) used in a company exclusively. Thus the CSFs for this type of PMIS are similar to those of general information systems of the company. However, the latter are generally used by various project participants such as client, architect, constructor, sub-contractor and construction manager, and their quality is considerably more dependent on the capability of service providers.

This research aims to identify the CSFs for ASP-based PMIS, so that we can understand what the important items are for the users. This paper initially reviews the previous research on information systems' success factors and models. A set of potential CSFs was established based on the previous research.

In order to assess the relative importance of these factors, a questionnaire was completed by PMIS users. Relying on the questionnaire results, a factor analysis was conducted so that we could determine the final CSFs and form them into meaningful groups.

The CSFs will provide PMIS developers or application service providers with guidelines for PMIS evaluation and upgrades. For the users of PMIS, the CSFs will be selection guidelines among various service providers.

\footnotetext{
${ }^{1}$ PhD Student, Kwang-woon University, 447-1, Wolgye-Dong, Nowon-Gu Seoul, South Korea, selkizz@kw.ac.kr

${ }^{2}$ Assistant Professor, Kwang-woon University, 447-1, Wolgye-Dong, Nowon-Gu Seoul, South Korea, myazure@kw.ac.kr (*Corresponding Author)
} 


\section{IS SUCCESS MODEL}

After reviewing over 180 papers on IT investment assessment factors in the 1870's and 1980's, DeLone and McLean(1992) presented an IS Success Model with six factors related to the success of information systems: System Quality, Information Quality, User Satisfaction, System Use, Individual Impact, and Organizational Impact.

While the model integrates the comprehensive dependent variables used by IS researchers, there have been several criticisms. First, IS Use in the DeLone and McLean model contains too many meanings for it to be appropriately examined. IS Use is also argued to play a problematic and controversial role in modeling system success. Second, because User Satisfaction represents individual impacts of IS in an organizational setting, investigating the cause path from User Satisfaction to individual impacts is fruitless. Finally, and most importantly, the model does not explain clearly and fully the relationship between User Satisfaction and Individual/Organizational impacts (Edward et al. 2005).

FIGURE 1 .

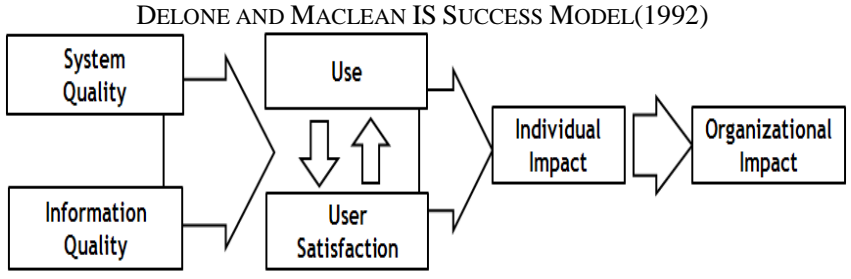

Ten years later, DeLone and McLean[1] presented an updated model reflecting the criticisms by other researchers and the situation at the time. As the service concept was added to IT with the use of the Internet, they increased the number of information system success factors to seven, including Service Quality, and analyzed the interdependence and correlation of these seven factors.

The difference between the existing models is as follows: first, the addition of service quality to reflect the importance of service and support in successful IS systems; and second, the collapsing of individual impacts and organizational impacts into more parsimonious net benefit constructs.

FIGURE 2

DELONE AND MACLEAN IS SUCCESS Model(2003)

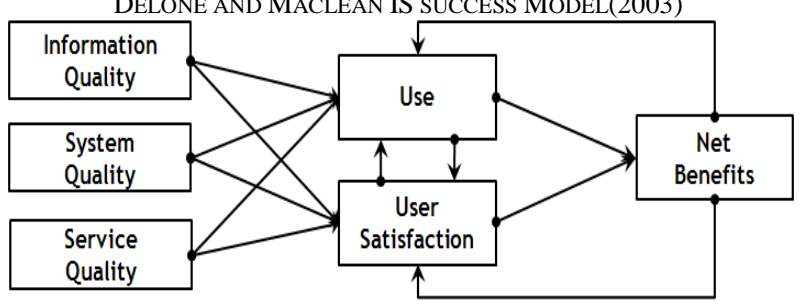

\section{PMIS IN CONSTRUCTION}

\section{A. PMIS Purpose and Function}

Construction PMIS is a new form of business and construction management where the client, supervisor, contractor, and subcontractors synthesize and share various information (for example, documents, drawings, pictures, and job records) to communicate promptly and accurately. This system leads to effective management and work efficiency, such as short construction periods and cost reduction.

The main agents in each phase are independent and the form of information differs in construction projects compared with the general manufacturing industry. Therefore, the seamless exchange of information is quite difficult. To overcome this problem, there is an increase in the need for construction PMIS as a supporting tool that allows main agents to share large amounts of information in real time.

For efficient work performance between the project related participants (client, contractor, and architect), PMIS supports three basic functions:

-Communication: It supports work efficiency through smooth communication by delivering related knowledge and information promptly between participants using an internal or external network.

-Collaboration: It supports an active cooperative management system among related participants for practical project management.

-Community: It supports the accumulation of related information and data through information sharing (Parks 2005).

ASP-based construction PMIS, the object of this study, has expected effectiveness factors such as cost reduction, needlessness of separate data processing, affinity for business environment change, and focus on main tasks. However, the following factors may inhibit its beneficial qualities: security of business information, limits in customization, lack of communication inside and outside the organization, lack of compatibility among the related supporting tools, and limits on standardizing information resources.

\section{B. PMIS Quality}

From the literature review, Quality factors were mainly formed following the DeLone and McLean IS Success Model (1992, 2003), which is composed of System Quality, Information Quality, and Service Quality. Therefore, we collect items based on the three factors of system quality, information quality and service quality as proposed by DeLone and McLean.

\section{1) System Quality}

System quality means the performance of the information processing system itself. As an essential quality element in the processing of tasks through computer-based information 
systems, it has been established as a critical factor for the success of information systems. Detailed items for assessing System Quality are accessibility, usability, efficiency and accuracy.

TABLE 1

SYSTEM QUALITY IN LITERATURE REVIEW

\begin{tabular}{l|c}
\hline \multicolumn{1}{c|}{ Item } & Author \\
\hline $\begin{array}{l}\text { Ease of use, usability, Esthetics, Functionality, Certainty, } \\
\text { Answerability, Accessability, Stability, Convenience, }\end{array}$ & $\begin{array}{c}\text { Jung and Jung } \\
\text { (2005) }\end{array}$ \\
$\begin{array}{l}\text { Sympathy } \\
\text { Convenience, Simplicity, Accuracy, Reliability, Speed, } \\
\text { Availability, Stability, Compatibility, Accessability, }\end{array}$ & Kim (2007) \\
\hline $\begin{array}{l}\text { Speed, Reliability, Availability } \\
\text { Speed, Stability, Obstacle }\end{array}$ & Kim (2007) \\
\hline $\begin{array}{l}\text { Convenience, Reliability } \\
\text { Simplicity of use, Accessability, Accuracy, Flexibility, }\end{array}$ & $\begin{array}{c}\text { Han and Lim } \\
\text { (1997) }\end{array}$ \\
\hline $\begin{array}{l}\text { Reliability, Efficiency } \\
\text { Efficiency, Ease of use, Convenience of access }\end{array}$ & $\begin{array}{c}\text { DeLone and } \\
\text { McLean }\end{array}$ \\
\hline $\begin{array}{l}\text { Flexibility, Interoperability, Functionability } \\
(1992,2003)\end{array}$ \\
$\begin{array}{l}\text { Rapid access, Quick error recovery, Security, } \\
\text { Correct operation \& Computation, Coordination } \\
\text { Balanced payment, }\end{array}$ & $\begin{array}{c}\text { Edward et } \\
\text { al.(2008) }\end{array}$ \\
\hline
\end{tabular}

\section{2) Information Quality}

Information systems are created to provide useful decision making information to individuals and groups by storing, keeping, processing and managing information resources. Their values are realized when the information provided is applied to operations. Swanson(1974) claimed that information quality is a critical factor that determines the success of information systems, and defined detailed factors for assessing information quality such as the rapidity of information resource acquisition and the usefulness of information resources. Meanwhile, Zmud(1979) insisted that accuracy and timeliness are the critical factors which determine information quality after he developed and empirically analyzed various information quality assessment factors.

TABLE 2

INFORMATION QUALITY IN LITERATURE REVIEW

\begin{tabular}{l|c}
\hline \multicolumn{3}{c}{ INFORMATION QUALITY IN LITERATURE REVIEW } \\
$\begin{array}{l}\text { Accuracy, Ability of Understanding, Availability, } \\
\begin{array}{l}\text { Precise, Currency, Conciseness, Consistency, } \\
\text { Interpretation, fidelity. }\end{array}\end{array}$ & Kim(2007) \\
$\begin{array}{l}\text { Accuracy, Conformance, Correlation, Timeliness, } \\
\text { Completeness, Significance }\end{array}$ & Kim(2007) \\
\hline $\begin{array}{l}\text { Accuracy, Component type, Completeness, Timeliness } \\
\text { Accuracy, Screen configuration adequacy, Offering }\end{array}$ & Park(2004) \\
\hline $\begin{array}{l}\text { information diversity, Timeliness } \\
\text { Timeliness, Accuracy }\end{array}$ \\
$\begin{array}{l}\text { Accuracy, Immediate, Reliability, Completeness, } \\
\text { Adequacy of format, Ability of Understanding }\end{array}$ & $\begin{array}{c}\text { Han and Lim } \\
(1997)\end{array}$ \\
\hline $\begin{array}{l}\text { Usefulness, Readability, Clarity, Format, Appearance, } \\
\text { accuracy, Currency, Completeness, Timeless, }\end{array}$ & $\begin{array}{c}\text { DeLone and } \\
\text { McLean } \\
\text { Comparability, Usability }\end{array}$ \\
\hline
\end{tabular}

\begin{tabular}{l|c}
\hline Integrated and better quality of information & Edward.(2008) \\
\hline $\begin{array}{l}\text { Business profitability, Perceived benefits, Improved } \\
\text { decision quality and performance, }\end{array}$ & $\begin{array}{c}\text { Liu and } \\
\text { Arnett(2000) }\end{array}$ \\
\hline Accuracy, Completeness, Consistency, Timeless & $\begin{array}{c}\text { Ballou and Pazer } \\
(1987)\end{array}$ \\
\hline
\end{tabular}

\section{3) Service Quality}

ASP-based PMIS is a type of outsourcing service for information systems which provides various services for products, hardware and software installation, maintenance and $\mathrm{A} / \mathrm{S}$ services. Thus, service quality is an important success factor for information systems and must be assessed. Information system service quality is actively researched in marketing and business administration areas. Widely used Service Quality assessment tools include SERVQUAL developed by Parasuraman et al.(1998) and SERVPERF which was derived from a criticism of SERVQUAL.

TABLE 3

SERVICE QUALITY IN LITERATURE REVIEW

\begin{tabular}{l|c}
\hline \multicolumn{1}{c|}{ Item } & Author \\
\hline $\begin{array}{l}\text { Diversity, Correspondence, Speed, Reliability, Kindness, } \\
\text { Reactivity, Convenience, Supportability }\end{array}$ & $\begin{array}{c}\text { Jung and Jung } \\
(2005)\end{array}$ \\
\hline $\begin{array}{l}\text { Response at once, Reliability, Confidence, Sympathy } \\
\text { Kervice speed, Comply with hours of employee, }\end{array}$ & Park(2004) \\
$\begin{array}{l}\text { Speciality of the service provider, Sympathy about the } \\
\text { client company }\end{array}$ & Park \\
$\begin{array}{l}\text { Operation of the information center, Education and } \\
\text { support for user and so on }\end{array}$ & $\begin{array}{c}\text { Joe and Lee } \\
\text { (1997) }\end{array}$ \\
\hline $\begin{array}{l}\text { Reliability, Assurance, Tangibles, Empathy, } \\
\text { Responsiveness }\end{array}$ & $\begin{array}{c}\text { Parasuraman } \\
\text { et al.(1998) }\end{array}$ \\
\hline $\begin{array}{l}\text { Quick, Responsiveness, Assurance, Reliability, Empathy } \\
\text { McLean } \\
\text { (1992, 2003) }\end{array}$ \\
\hline Reliability, Availability of service & \begin{tabular}{c} 
Edward.(2008) \\
\hline
\end{tabular}
\end{tabular}

Through this prior study on quality assessment and a successful information system model, we collected detailed information about the factors to be used in this study. Based on this, items with similar meanings or for specific information systems were deleted, and items reflecting the construction industry and construction information management were added to assess the quality of PMIS construction. In order to ascertain the validity of these assessment items, we interviewed PMIS construction developers and reviewed the overlap and appropriateness of the items. 
TABLE 4

FACTOR OF PMIS QUALITY

\begin{tabular}{l|l}
\hline Q1 & $\begin{array}{l}\text { PMIS should be compatible with Software such as Excel, P3, } \\
\text { CAD }\end{array}$ \\
\hline Q2 & PMIS should connect to IT tool such as PDA, RFID, USN \\
\hline Q3 & $\begin{array}{l}\text { System functions and configuration should be construct that } \\
\text { easy to use user }\end{array}$ \\
\hline Q4 & $\begin{array}{l}\text { System screen configuration (a button, symbol, letter/ Image } \\
\text { size) or document formats should be suitable }\end{array}$ \\
\hline Q5 & Input/Output data should be easy(up/download, printing) \\
\hline Q6 & Access to system should be not difficult \\
\hline Q7 & System should maintain the steady state \\
\hline Q8 & Search of information should be easy \\
\hline Q9 & $\begin{array}{l}\text { PMIS should offer Information to users on real time (human } \\
\text { resource/ material/ approval information) }\end{array}$ \\
\hline Q10 & Registered information in system should be proper \\
\hline Q11 & $\begin{array}{l}\text { Registered information in system should be used without } \\
\text { correction }\end{array}$ \\
\hline Q12 & Registered information in system should be sufficient \\
\hline Q13 & $\begin{array}{l}\text { Registered information in system should be related to user's } \\
\text { task. }\end{array}$ \\
\hline Q14 & $\begin{array}{l}\text { Reaction of PMIS service provider should be quick in the } \\
\text { situation }\end{array}$ \\
\hline Q15 & $\begin{array}{l}\text { Technical support of PMIS service provider for maintenance } \\
\text { and repair should be quick. }\end{array}$ \\
\hline Q16 & $\begin{array}{l}\text { Functions of PMIS should be useful according to the project } \\
\text { characteristic and user's role }\end{array}$ \\
\hline Q17 & Options should be various depending on the user's task \\
\hline Q18 & Education for PMIS user should be provided \\
\hline Q19 & User's manual and advice should be provided during usage \\
\hline Q20 & $\begin{array}{l}\text { PMIS service provider should possess knowledge of } \\
\text { construction field }\end{array}$ \\
\hline Q21 & User should feel security about data \\
\hline Q22 & User should trust capability of PMIS service provider \\
\hline Q23 & PMIS service provider should faithful \\
\hline &
\end{tabular}

\section{RESEARCH METHODOLOGY}

The data used to test the research model were obtained from a sample of experienced users (Construction Manager and Constructor) of PMIS. To increase the generalizability of the results, the respondents were spread across the construction site. Each of the items was measured on a varying seven-point scale. Likert scales (1-7), with anchors ranging from "strongly disagree" to "strongly agree" were used for all questions. The questionnaire was sent by e-mail and mail.

A total of 253 usable responses were obtained. Detailed descriptive statistics relating to the respondents' characteristics are shown in table5.

TABLE 5

CHARACTERISTICS OF THE RESPONDENTS $(\mathrm{n}=253$ )

\begin{tabular}{|c|c|c|c|}
\hline \multicolumn{2}{|c|}{ Measure } & Frequency & $\%$ \\
\hline \multirow{2}{*}{$\begin{array}{c}\text { Project } \\
\text { Characteristic }\end{array}$} & Public Project & 113 & $44.7 \%$ \\
\hline & Private Project & 140 & $55.3 \%$ \\
\hline \multirow{2}{*}{$\begin{array}{l}\text { Sector of the } \\
\text { respondent' } \\
\text { Organization }\end{array}$} & $\begin{array}{l}\text { Construction } \\
\text { Management }\end{array}$ & 140 & $55.3 \%$ \\
\hline & Construction & 113 & $44.7 \%$ \\
\hline \multirow{3}{*}{ Experience } & Less than 2 years & 44 & $17.39 \%$ \\
\hline & 3 5years & 32 & $17 \%$ \\
\hline & 5 10years & 50 & $19.76 \%$ \\
\hline
\end{tabular}

\begin{tabular}{c|c|c|c}
\hline & $10 \sim 15 y e a r s$ & 24 & $9.49 \%$ \\
\cline { 2 - 4 } & More than 15years & 92 & $36.36 \%$ \\
\hline
\end{tabular}

\section{DATA ANALYSIS AND FINDING}

\section{A. Factor analysis of the CSFs}

Analysis is used to identify a relatively small number of factor groups that can be used to represent relationships among sets of many inter-related variables. In this survey, this method was used to determine the groupings of the 23 CSFs.

According to Pallant (2001), 2 main issues need to be considered in determining whether a data set is suitable for factor analysis: sample size and the strength of the relationship among the factors. In terms of sample size, according to Hair et al. [20], at least 4-5 times the number of variables is appropriate. Also, Nunnalyy (1978) suggested that the sample size should be at least 10 times the number of variables. However, it is usually suggested that the sample size be at least 5 times the number of variables. There were 23 factors in this survey; therefore, according to Nunnalyy's (1978) recommendation, 230 respondents should be obtained in this study. Therefore, the sample size was sufficient for factor analysis. In terms of the strength of relationship among the factors, the correlation matrix (Tabachnik, 1996), the Bartlett's test of sphericity (Bartlett, 1954) and the Kaiser-Myer-Olkin (KMO) (Kaiser, 1970) test were recommended.

Most values in the correlation matrix are larger than 0.3, the Bartlett's test of sphericity is significant $(p<0.05)$, and the value of the KMO index is above 0.6, suggesting that the data set is suitable for factor analysis. In this survey, all of the correlation coefficients were above 0.3 , the Bartlett's test of sphericity was significant $(\mathrm{p}<0.05)$ (Table 6), and the value of the KMO index was 0.950 (above 0.6 ). The results of these tests confirmed that the data were appropriate for factor analysis.

The number of factors is determined on the basis of Eigen Value. a 3-component with eigen value greater than 1.0 was produced based on a varimax rotation of principal component analysis (Table 6). The three factor groupings explain $66.191 \%$ of the variance. Each of the CSFs belonged to only one of the groupings, with the value of factor loading exceeding 0.5

Q3's System functions and configuration should be constructed so it is easier to use and is loaded in Components 1 and 3, but it was not deleted. This is because the item is higher than the mean average of the total item and does not interfere with the unidimensionality. Q3 relates more to Component 1 in terms of content. It is therefore considered to be the same as Component 1 .

The following table shows the results of factor analysis. 
TABLE 6

\begin{tabular}{|c|c|c|c|c|c|}
\hline \multicolumn{6}{|c|}{ RESULT OF RELIABILITY AND VALIDITY TEST } \\
\hline Component & Items & $\begin{array}{c}\text { Factor } \\
\text { Loading }\end{array}$ & $\begin{array}{l}\text { Eigen } \\
\text { value }\end{array}$ & Cumulative \% & Cronbach' $\alpha$ \\
\hline \multirow[t]{10}{*}{1} & Q12 & 0.783 & \multirow[t]{10}{*}{12.684} & \multirow[t]{10}{*}{55.149} & \multirow[t]{10}{*}{0.941} \\
\hline & Q11 & 0.776 & & & \\
\hline & Q10 & 0.709 & & & \\
\hline & Q13 & 0.704 & & & \\
\hline & Q9 & 0.668 & & & \\
\hline & Q3 & 0.650 & & & \\
\hline & Q16 & 0.643 & & & \\
\hline & Q4 & 0.632 & & & \\
\hline & Q8 & 0.625 & & & \\
\hline & Q17 & 0.544 & & & \\
\hline \multirow[t]{8}{*}{2} & Q19 & 0.816 & \multirow[t]{8}{*}{1.550} & \multirow[t]{8}{*}{61.890} & \multirow[t]{8}{*}{0.926} \\
\hline & Q20 & 0.752 & & & \\
\hline & Q18 & 0.750 & & & \\
\hline & Q23 & 0.726 & & & \\
\hline & Q22 & 0.711 & & & \\
\hline & Q21 & 0.647 & & & \\
\hline & Q14 & 0.596 & & & \\
\hline & Q15 & 0.558 & & & \\
\hline \multirow[t]{5}{*}{3} & $\mathrm{Q} 2$ & 0.697 & \multirow[t]{5}{*}{1.019} & \multirow[t]{5}{*}{66.322} & \multirow[t]{5}{*}{0.835} \\
\hline & Q1 & 0.694 & & & \\
\hline & Q7 & 0.609 & & & \\
\hline & Q6 & 0.607 & & & \\
\hline & Q5 & 0.603 & & & \\
\hline \multicolumn{5}{|c|}{ Kaiser-Meyer-Olkin measure of sampling adequacy } & 0.950 \\
\hline \multirow{3}{*}{\multicolumn{3}{|c|}{ Bartlett's test of Sphericity }} & \multicolumn{2}{|c|}{ Approx. Chi-Square } & 4632.666 \\
\hline & & & \multicolumn{2}{|c|}{ df. } & 253 \\
\hline & & & \multicolumn{2}{|r|}{ Sig. } & 0.000 \\
\hline
\end{tabular}

\section{1) Component 1: Information Quality}

This component, which accounted for $55.149 \%$ (Table 6) of the total variances between CSFs, was relatively more important than the other two components. It indicated that experienced users (Construction Manager and Constructor) in Korea consider PMIS information quality during construction. Therefore, this component, which is related to information quality, could be illustrated by Q12, Q11, Q10, Q13, Q9, Q3, Q16, Q4, Q8 and Q17.

Information quality factors can be largely divided into three groups: Simplicity of information acquisition $(\mathrm{Q} 3, \mathrm{Q} 4$, Q8, Q9), Quality of provided information (Q10, Q11, Q12) and Relevance of provided information (Q13, Q16, Q17).

'The Relevance of provided information': As one of the expected effects of ASP-based PMIS, customization should be evaluated. Items related to the relevance of provided information consist of Q13, Q16 and Q17.

'Registered information in the system should be used without correction': If separate work is required for PMIS input and output information, it can cause duplications. Thus, whether the PMIS input and output information can be used as is, without any modification, must be ascertained.

\section{2) Component 2: Service Quality}

This component ranked second among the three components. As shown in Table 6, service quality factors can be largely divided into three groups: Reactivity (Q14,
Q15), Support (Q18, Q19, Q20) and Reliability (Q21, Q22, Q23).

'The PMIS service provider should possess knowledge of the construction field': If the system is developed with no regard to user operations, it will cause inefficient operations. Thus, the developer's possession of expert knowledge of the construction industry will affect the quality of PMIS.

'User should feel security about data': It is one of the factors that inhibits the activation of ASP-based PMIS. Thus, continuous improvement is needed through evaluation.

\section{3) Component 3: System Quality}

Though this component is the lowest ranked among the three components (Table 6), it is indispensable for PMIS's CSFs. System quality is the performance of the information processing system and how it works when systems are related. Service quality factors can be largely divided into two groups: Connectivity (Q1, Q2), Usefulness (Q5, Q6, Q7).

'Connectivity': The construction industry developed PMIS as a support tool to help solve the inefficient exchange of information between workers due to the use of different information formats in each work step. To meet this PMIS requirement, it is necessary to assess the connectivity between the software and IT tools used for each operation and the PMIS

\section{B. Validation of the CSFs}

1) Testing for reliability

A $\alpha$ value higher than 0.7 is considered to be relatively more reliable. As shown table 6 , the result of the reliability test is 0.835 to 0.941 . Therefore, this provides evidence that all the factors have a high internal consistency and reliability.

\section{2) Testing for content validity}

To ensure the content validity, our survey was established from the existing literature. In addition, our measures were constructed by adopting constructs validated by other researchers. Also, we conducted pretesting with experts in the field of PMIS in construction. After the pretesting, these items were modified to fit the construction context studied.

\section{3) Testing for construct validity}

Construct validity was used to check for unidimensionality. Unidimensionality means that a single factor is extracted for each test. Each factor grouping was evaluated by factor analysis for construct validity. The table 7 presents results of the unidimensional test. Since all of the $\mathrm{KMO}$ values were greater than 0.5 , and the percentage of variance explained by each component was more than $50 \%$, all 3 components were demonstrated to be unidimentional. 
TABLE 7

RESULT OF UNIDIMENSIONALITY TEST

\begin{tabular}{c|c|c|c|c}
\hline Component & $\begin{array}{c}\text { KMO } \\
\text { value }\end{array}$ & $\begin{array}{c}\text { Factor } \\
\text { Loading }\end{array}$ & $\begin{array}{c}\text { Eigen } \\
\text { value }\end{array}$ & $\begin{array}{c}\text { Percentage variance } \\
\text { explained }\end{array}$ \\
\hline 1 & 0.921 & $0.747-0.856$ & 6.549 & 65.492 \\
2 & 0.896 & $0.753-0.861$ & 5.292 & 66.152 \\
3 & 0.789 & $0.679-0.835$ & 3.054 & 61.084 \\
\hline
\end{tabular}

\section{CONCLUSION}

The importance of information technology (IT/IS) in architectural/engineering/construction (A/E/C) industries has grown exponentially in the past few decades. As one of the key IT applications, PMIS has played a significant role in construction management processes.

The main contribution of this study is identifying an ordered and grouped set of CSFs for PMIS quality in the Korean construction industry.

The 23 CSFs were identified through a literature review of research such as DeLone and McLean's Is Success Model and face-to-face interviews. Using factor analysis, the 23 CSFs were grouped.

Factor analysis results are as follows. 1) Information Quality (10 Items; Simplicity of information acquisition (Q3, Q4, Q8, Q9), Quality of provided information (Q10, $\mathrm{Q} 11, \mathrm{Q} 12)$ and Relevance of provided information (Q16, Q17)). 2) Service Quality (8 Items; Reactivity (Q14, Q15), Support (Q18, Q19, Q20), Reliability (Q21, Q22, Q23)). 3) System Quality (5 Items; Connection (Q1, Q2), Usefulness (Q5, Q6, Q7)).

The result of this survey is somewhat simple. However, it is important as a foundation for the research of PMIS Quality. Also, the CSFs will provide PMIS developers or application service providers with guidelines for PMIS evaluation and upgrades. For the users of PMIS, the CSFs will be used as selection guidelines among various service providers.

In order to improve the ability to describe the relationships between the critical success factors of the construction PMIS (which were derived in this study), the success model for ASP-based PMIS needs to be verified by applying additional parameters such as intended use and user satisfaction that have been presented in existing information system success models.

\section{REFERENCES}

[1] J.H. Yu, H.S. Lee, "Evaluation Model for Information Systems Benefits in Construction Management Process", Journal of Construction Engineering and Management, vol. 132, no. 10, pp. 1114-1121, 2006.

[2] J.H. Yu, H.S. Lee, "Success Factors for Implementing Construction Project Management Information System(PMIS) based on the Characteristics of Construction Management Tasks", Journal of Architectural Institute of Korea, vol. 20, no. 5, pp. 103-110, 2004.

[3] L. Raymond, F. Bergeron, "Project management information systems: An empirical study of their impact on project managers and project success", International journal of Project Management, vol. 26, no. 2, pp. 213-220, 2008.
[4] W.H. DeLone, E.R. McLean, "Information system success: The Quest for the Dependent Variable", Information Systems Research, vol. 3, no. 1, pp. 60-95, 1992.

[5] J.G. Edward, B. Glassberg, Y. J. Kim, S. Lawrence, S. K. Shin, “An experimental investigation of Web-based information systems success in the context of electronic commerce", Decision Support Systems, vol. 39, no. 3, pp. 485-503, 2005.

[6] W.H. DeLone, E.R. McLean, "The Delone and McLean Model of Information system success: A ten-year update", Journal of Management Information Systems, vol. 19, no. 4, pp. 9-30, 2003.

[7] Y.S. Jung, C.H. Jung, "An Empirical Analysis on the Success Factors of ASP Services" Information System Research, vol. 14, no. 2, pp. 2553,2005

[8] G. Kim, "A Scale Development for Measuring User Satisfaction with GKMS", Journal of the Korea Association for Policy Analysis and Evaluation, vol. 17, no. 4, pp. 117-148, 2007.

[9] J.G. Kim, "Exploring the Success Factors of ASP based Information System: From the Perspective of Two Factor Theory", e-Business Research, vol. 8, no. 1, pp. 21-35, 2007.

[10] J.H. Park, J.G. Kim, J.W. Kim, H.S. Lee, "Deriving an ASP Success Model: An Application to Small Business", Business Information Research, vol. 14, no. 1, pp. 43-58, 2004.

[11] M.H. Jeo, C.K. Lee, "An Empirical Analysis on Success Factor and Success Model of Information System: Focus on a local government", Journal of Korea Administration, vol. 31, no. 1, pp. 145-162, 1997.

[12] Y.C .Han, S.T. Lim, "An Empirical Study on Evaluating Effectiveness of Information System", Journal of Management Research, vol. 12, no. 1, pp. 257-288, 1997.

[13] E.W.N. Bernroider, "IT governance for enterprise resource planning supported by the DeLone-McLean model of information systems success", Information \& Management, vol. 45, no. 5, pp..257-269, 2008

[14] L. Chang, P.A. Kirk, "Exploring the factors associated with Web site success in the context of electronic commerce", Information \& Management, vol. 38, no. 1, pp. 23-33, 2000.

[15] E.B. Swanson, "Management information system, Appreciation and involvement", Management Science, vol. 21, no. 2, pp. 178-188, 1974

[16] R.W. Zmud, "Individual differences and MIS success: a review of the empirical literature", Management Science, vol. 25, no. 10, pp. 966979, 1979.

[17] D.P. Ballou, H.L. Pazer, "Cost/quality tradeoffs for control procedures in information systems", Omega, vol. 15, no. 6, pp. 509$521,1987$.

[18] A. Parasuraman, V.A. Zeithaml, L.L. Berry, "SERVQUAL: A multiitem scale for measuring consumer perceptions of sesrvice quality", Journal of Retailing, vol. 64, no. 1, pp. 13-30, 1998

[19] J. Pallant, "SPSS Survival Manual", Open University Press, Buckingham and Philadelphia, 2001.

[20] J.F. Hair, L. Ronald, R.E.A. Tatham, B. William, "Multivariate Data Analysis, Multivariate Data Analysis", Prentice-Hall Int., 1998.

[21] J.O. Nunnalyy, "Psychometric Theory". New York, McGraw-Hill, 1978.

[22] B.G. Tabachnik, L.S. Fidell, "Using Multivariate Statistics", $3^{\text {rd }}$ ed., New York, Harper Collins, 1996.

[23] M.S. Bartlett, "A note on the multiplying factors for various chi square approximations", Journal of the Royal Statistical Society, vol.16, no.2, pp. 296-298, 1954.

[24] H.F. Kaiser, "A second generation little jiffy", Psychometrika, vol. 35, no. 4, pp. 401-415, 1970.

[25] T. Aksorn, B.H.W. Hadikusumo, "Critical Success factors influencing safety program performance in construction projects", Safety Science, vol. 46, no. 4, pp. 709-727, 2008. 